\title{
Employer Checks of Immigration Status and Employment
}

\section{Law}

Bernard Ryan*

\section{Introduction}

This chapter will address the employment law implications of checks by employers on the right to work under immigration law of potential and current employees. ${ }^{1}$ Its theme is that there is a structural tension between employer duties to the state under immigration law and their obligations to workers under employment law. The core difficulty is that immigration law tends to be absolute in nature, as workers generally either do or do not have the right to be employed by the employer in question. By contrast, in recognition of both the reality and the diversity of employment relationships, employment law generally holds employers to standards of reasonableness in their treatment of potential and current employees.

The chapter as a whole will show how difficult it can be to interpret employment law obligations when immigration law duties upon employers are in play. The argument of the chapter will be developed as follows. Section II will outline the legal

\footnotetext{
${ }^{*}$ Bernard Ryan is Professor of Migration Law at the University of Leicester.

${ }^{1}$ The term 'employment law' is used here to include obligations under discrimination law which concern employment relationships.
} 
penalties in Britain upon those who employ workers who lack permission to work under immigration law. Section III will consider the potential role of a right to work and of discrimination law when employers conduct checks on immigration during recruitment. Section IV will address the two legal issues concerning checks during the employment relationship: whether discrimination law constrain such checks, and whether suspension of the employee is possible when the outcome of any such checks is uncertain or negative. Finally, section V will consider the implications of the law of unfair dismissal for employer decisions to terminate the employment relationship because of an employee' apparent lack of a right to work.

Throughout the chapter, it will be assumed that employers will seek to comply both with their legal obligations deriving from the law on employer penalties, and with their legal duties to employees. It will also be assumed that employers potentially have autonomous business reasons for wishing to ensure that their potential and current employees have a secure legal right to work. For that reason, the focus will be on 'employer checks' in a general sense, including employer practices which seek to check an individual's entitlement to work, and employer decisions concerning potential or actual employees which follow those checks.

\section{Employer Penalties in British Immigration Law}

The Asylum and Immigration Act 1996 was the first piece of legislation in Britain to specifically penalize employers who hired workers who lacked permission to work under immigration law. ${ }^{2}$ In comparative terms, Britain was a relatively late adopter of

\footnotetext{
${ }^{2}$ For a discussion, see B Ryan, 'Employer Enforcement of Immigration Law after Section Eight of the Asylum and Immigration Act 1996' (1997) 26 ILJ 136.
} 
the principle of employer penalties. For example, employer penalties were introduced in France and Germany in 1972, and a requirement for such sanctions was included in the ILO's Migration for Employment Convention of $1975 .{ }^{3}$ In 1976, the European Commission proposed a Directive making employer penalties obligatory for the then nine Member States, but found itself blocked by Britain's opposition. ${ }^{4}$ The United States introduced employer penalties with the Immigration Reform and Control Act 1986. ${ }^{5}$ Provision for employer penalties was also included in the United Nations Migrant Workers Convention, which was agreed in 1990 and came into force in 2003. More recently, EU Directive 2009/52 requires employer penalties of most EU Member States, and specifies in detail the form that they are to take. ${ }^{6}$

${ }^{3}$ See P Martin and M Miller, 'Employer Sanctions: French, German and US Experiences' (ILO International Migration Paper 36 2000) 7-32; and Migrant Workers (Supplementary Provisions) Convention 1975 (ILO No 143) 1120 UNTS 323, Article 6.

${ }^{4}$ See Commission, 'Proposal for a Council Directive on the harmonization of laws in the Member States to combat illegal migration and illegal employment' (Communication) COM (76) 331 final; Commission, 'Proposal for a Council Directive concerning the approximation of the legislation of the Member States, in order to combat illegal migration and illegal employment' (Communication) COM (78) 86 final; Statement by Home Office Minister Shirley Summerskill, House of Commons Debates (24 June 1977, cols 19952003).

${ }^{5}$ Discussed in Martin and Miller (n 3) 33-52.

${ }^{6}$ Council Directive (EC) 2009/52 providing for minimum standards on sanctions and measures against employers of illegally staying third-country nationals [2009] OJ L168/24 (Employer Sanctions Directive). The Directive applies to the twenty-four EU member states other than Denmark, Ireland, and the United Kingdom. 
The 1996 Act relied upon criminal penalties alone, and therefore required a criminal standard of proof. That approach was associated with a low level of prosecution activity, with only twenty-five convictions under the 1996 Act in the period between 1998 and 2004. ${ }^{7}$ To obviate the need for a criminal prosecution, a new system of 'civil' employer penalties was legislated for by the Immigration Asylum and Nationality Act 2006 and the Immigration (Restrictions on Employment) Order 2007. ${ }^{8}$ That scheme came into force on 29 February 2008, for employees commencing employment on or after that date. Under the civil penalty scheme, where an immigration official finds an apparent breach of the rules, the employer is issued with 'notice of liability' to a fine. There is a maximum fine of $£ 10,000$ per worker, which is reduced for first and second offences, where the employer has made partial checks, and where the employer has cooperated with the Border Agency. ${ }^{9}$ The onus is on the

${ }^{7}$ Based on Home Office, Control of Immigration: Statistics-United Kingdom $2000(\mathrm{Cm}$ 5315, November 2001), Table 7.5 and Home Office, Control of Immigration: StatisticsUnited Kingdom 2004 (Cm 6690, November 2005), Table 6.5.

${ }^{8}$ Immigration Asylum and Nationality Act 2006, ss 15-25; Immigration (Restrictions on Employment) Order 2007, SI 2007/3290.

${ }^{9}$ The maximum fine is set out in the Immigration (Employment of Adults Subject to Immigration Control) (Maximum Penalty) Order 2008, SI 2008/132. The possible reductions are set out in UK Border Agency, Comprehensive Guidance for Employers on Preventing Illegal Working (November 2010) appendix F. The Government has announced its intention to amend secondary legislation in 2014 to introduce new maxima of $£ 15,000$ for a first breach, and of $£ 20,000$ for further breaches: Home Office, Strengthening and Simplifying the Civil Penalty Scheme to Prevent Illegal Working: Consultation Document (July 2013) paras 28 and 29. 
employer to object to the fine, or to its amount, to the UK Border Agency or on appeal to a county or sheriff court. ${ }^{10}$ In practice, the introduction of civil penalties led to a step-change in the extent of penalization of employers. Between 29 February 2008 and the end of 2012 , a total of 8,169 penalty notices had been issued to employers. ${ }^{11}$

Under both the 1996 and 2006 statutory frameworks, employers have been liable for a penalty only if they have actually employed someone who lacks permission to work. The purpose of checks of documents is to provide an employer with a defence should an employee's lack of permission come to light. There is no legal obligation on the employer to check anyone's immigration status, and accordingly no legal bar to the employer's 'taking their chances' that an employee is entitled to work. The position in the UK may be contrasted with that in the United States, and under the EU's 2009 Employer Sanctions Directive, each of which includes a specific employer duty to make checks of status. ${ }^{12}$ The 1996 list of documents that employers could rely

${ }^{10}$ Immigration Asylum and Nationality Act 2006, ss 16-17. The Government has proposed that the making an objection to the Secretary of State should be a pre-condition to the right of appeal to a court: see Home Office, Consultation Document (n 9) paras 47 and 48 . That proposal is included in the Immigration Bill, which is before Parliament at the time of writing (2013-2014 House of Commons Bills 110, clause 39).

${ }^{11}$ Based on written answer given by Immigration Minister, Mark Harper, House of Commons Debates (10 April 2013, col 1147W).

${ }^{12}$ For the United States, see Immigration and Nationality Act 1952, s 274A(a)(1)(b). In the case of the European Union, Article 4(1) of the Employer Sanctions Directive provides that 'Member States shall oblige employers to: (a) require that a third-country national before 
upon for their statutory defence was comparatively broad, and therefore implied less of a constraint upon employers. ${ }^{13}$ For example, the list included official documents bearing a national insurance number, even though that number did not necessarily prove a current right to work. The list also left open the possibility of impersonation, as many of the listed documents — again, including official documents bearing a national insurance number-lacked a photograph. In response to concerns that the list was too open, an amendment in 2004 meant that the only documents that could be relied upon without further proof were passports, identity documents, and immigration documents which contained a photograph. ${ }^{14}$ In other cases, specified combinations of two documents were required. That modified approach was retained when civil penalties were introduced under the 2006 Act.

The introduction of the civil penalty scheme tightened the requirements concerning employer checks in two respects. Firstly, re-checks of documents are now required in some circumstances. Under both the 1996 and 2006 Acts, the employer's defence has depended upon a check being made before the employment relationship commences. ${ }^{15}$ Under the civil penalty scheme, in addition, re-checks of status are

\footnotetext{
taking up the employment holds and presents to the employer a valid residence permit or other authorisation for his or her stay'.

${ }^{13}$ Immigration (Restrictions on Employment) Order 1996, SI 1996/3225.

${ }^{14}$ Immigration (Restrictions on Employment) Order 2004, SI 2004/755.

${ }^{15}$ Asylum and Immigration Act 1996, s 8(2)(a) and Immigration (Restrictions on Employment) Order 2007, Articles 3(2) and 5. The requirement to make a check prior to the employment is problematic where the business is subsequently transferred to a new owner, who risks being exposed to liability for any failure on the part of the initial owner.
} For this reason, the UK Border Agency allows a defence by a new owner where they make 
required where an employee has not presented evidence of a long-term right to work. Within the implementing legislation of 2007, 'List A' documents are those which do show a long-term right to work, mainly because they demonstrate possession of a European Economic Area (EEA) nationality, permanent residence deriving from EU law, or indefinite leave based on British law. Where List A documents are presented, an employer may rely upon the statutory defence for the remainder of the employment relationship. ${ }^{16}$ In contrast, documents which give evidence of a right to work which is limited in time are covered by 'List B', and protect the employer only for twelve months from the date on which the document was presented. ${ }^{17} \mathrm{~A}$ further change which the Government plans will see the general twelve-month rule removed, and its replacement by a requirement to re-check an individual's right to work on the date that the previous immigration permission expires. ${ }^{18}$

Secondly, the requirements concerning the content of checks and records are tighter under the civil penalty scheme. The 1996 Act simply required an employer to retain a copy of the key parts of passport or identity document, or of the whole of the document in other cases. ${ }^{19}$ In addition to requiring a copy to be made on much the same basis as before, the legislation implementing the civil penalty places the following specific obligations upon the employer: to take 'all reasonable steps to check the validity of the document', to satisfy themselves that any photograph is of a check within twenty-eight days of the transfer of a business: UK Border Agency, Full Guide for Employers on Preventing Illegal Working in the UK (May 2012) 73.

${ }^{16}$ Immigration (Restrictions on Employment) Order 2007, Article 3.

${ }^{17}$ Immigration (Restrictions on Employment) Order 2007, Article 4.

${ }^{18}$ Home Office, Consultation Document (n 9) paras 44-46.

${ }^{19}$ Immigration (Restrictions on Employment) Order 1996, Schedule, Part III. 
the person concerned, to satisfy themselves that any date of birth given is 'consistent with the appearance' of the person concerned, and to take 'all other reasonable steps' to check that the person 'is the rightful owner of the document' in question. These changes must be thought to have increased the likelihood that employers will query documents presented to them.

Under both the 1996 and 2006 schemes, an employer has remained liable, irrespective of any checks, where they knew that a worker is employed without permission. The 1996 Act provided that the statutory defence was unavailable where an employer 'knew that ... employment of the employee would constitute an offence under this section' ${ }^{20}$ The use of the past tense in that Act suggested that the principle was intended to apply only at the point of hiring. It followed that an employer did not commit an offence if they made a bona fide check on status prior to hiring, and only thereafter acquired knowledge that an individual did not have, or no longer had, a right to work. Under the 2006 Act, it is stated that employer knowledge 'at any time during the period of the employment' that a person lacks permission to work precludes the employer's reliance upon the statutory defence to the civil penalty. ${ }^{21}$ Such knowledge also exposes an employer to a specific criminal offence, as the 2006 Act provides that 'a person ... commits an offence if he employs' another person, 'knowing that' the other person lacks permission to work, or to accept the

\footnotetext{
${ }^{20}$ Asylum and Immigration Act 1996, s 8(3).

${ }^{21}$ Immigration Asylum and Nationality Act 2006, s 15(4).
} 
employment in question. ${ }^{22}$ This use of the present tense implies that the criminal offence may be committed at any stage of the employment relationship. ${ }^{23}$

A final point is that, in cases where there may be an ongoing immigration application, assistance to employers is provided by the 'Employer Checking Service' (ECS) administered by UK Visas and Immigration. Confirmation of an individual's permission to work through the ECS is a precondition to the employer's statutory defence where the employer relies upon a worker's certificate of application as a nonEEA family member. ${ }^{24}$ Reliance upon the ECS is also required where the worker produces a registration card showing that they are an applicant for international protection with permission to take employment. ${ }^{25} \mathrm{~A}$ third case is that of individuals who apply for fresh leave under the Immigration Act 1971 before an initial period of leave has expired. In those circumstances, the initial leave, and any rights of employment which derive from it, are deemed to continue until the application is resolved, and any related appeal rights are exhausted..$^{26}$ Where a worker claims that

${ }^{22}$ Immigration Asylum and Nationality Act 2006, s 21(1) (emphasis added).

${ }^{23}$ The 2006 Act also introduced the possibility of a sentence of imprisonment for the criminal offence: Immigration Asylum and Nationality Act 2006, s 21(2). This is given particular relevance by the provision in the 2006 Act that, where an officer of a body corporate consented to, or connived in, the employment of workers who lacked permission, both the individual and the corporate body are guilty of an offence: Immigration Asylum and Nationality Act 2006, s 22. A similar provision had also been included in the 1996 Act but without the sanction of imprisonment: Asylum and Immigration Act 1996, s 8(5).

${ }^{24}$ Immigration (Restrictions on Employment) Order 2007, List B, point 3.

${ }^{25}$ Immigration (Restrictions on Employment) Order 2007, List B, points 4 and 6.

${ }^{26}$ Immigration Act 1971, s 3C. 
they have made an application for fresh leave, employers may use the ECS to check the status of any application or appeal. ${ }^{27}$ Given the inherent difficulty of ensuring upto-date information concerning applications and appeals, the ECS must, however, be considered an imperfect system.

\section{Employer Checks During Recruitment}

Two categories of legal question raised by employer checks of immigration status during recruitment are discussed in this section. Firstly, are there duties upon employers to recognize the right to work of certain employees? Secondly, which employer practices concerning checks are incompatible with discrimination law?

\section{Is there a legally enforceable right to work?}

When an employer checks immigration status during a recruitment process, is the employer under any general duty to recognize a worker's legal entitlement to work, or to take reasonable steps to investigate it? At the domestic law level, there appears to be no basis upon which any such obligations might be based. While the common law has historically recognized a right to pursue a lawful trade or occupation, it has done so only in relation to those who seek to regulate its practice. ${ }^{28}$ That principle does not

\footnotetext{
${ }^{27}$ See 'Employer Checking Service' <https://www.gov.uk/government/publications/employer-checking-service-form-checkemployees-right-to-work> accessed 17 March 2014.

${ }^{28}$ The leading statement of the principle is that of Lord Denning in Nagle v Fielden [1966] 2 QB 633; 644-5: 'The common law of England has for centuries recognised that a man has
} 
extend to individual employers, who remain free at common law to refuse to hire for any reason. $^{29}$

If there is an exception, it concerns persons with directly effective rights to work which flow from EU law-ie the nationals of other European Economic Area states and Switzerland, ${ }^{30}$ the family members of such persons, ${ }^{31}$ certain Turkish nationals and their resident family members, ${ }^{32}$ and refugees and beneficiaries of subsidiary

a right to work at his trade or profession without being unjustly excluded from it. He is not to be shut out from it at the whim of those having the governance of it.'

${ }^{29}$ For a discussion of the absence of a common law remedy for non-hiring, see B Hepple, 'A Right to Work?' (1981) 10 ILJ 65, 73.

${ }^{30}$ See Article 45 of the Treaty on the Functioning of the European Union (TFEU) [2010] OJ C 83/47; Article 28 of the Agreement on the European Economic Area [1994] OJ L 1/3 and Article 7(a) of the EU-Swiss Agreement on the Free Movement of Persons [2002] OJ L 114/6.

${ }^{31}$ In relation to these family members, see Article 23 of Council Directive (EC) 2004/38 on the right of citizens of the Union and their family members to move and reside freely within the territory of the Member States [2004] OJ L158/77 (Citizens Directive); Council Decision 158/2007 of 7 December 2007 amending Annex V (Free movement of workers) and Annex VIII (Right of establishment) to the EEA Agreement [2008] OJ L124/20 and Article 7(e) of the EU-Swiss Agreement on the Free Movement of Persons [2002] OJ L114/6.

${ }^{32}$ Turkish nationals acquire an unrestricted right to take employment after four years' lawful employment in a Member State, and their family members acquire the same right after five years' lawful residence: Article 6(1) and Article 7 of Decision 1/80 of the EEC-Turkey Association Council, available at <http://www.abgs.gov.tr/files/_files/okk_eng.pdf> accessed 17 March 2014. 
protection. ${ }^{33}$ As these rights are vertically directly effective, it is arguable that there is a duty on public employers to respect individuals' right to work. Moreover, in the specific case of the right to work of EU citizens, the Treaty provision in question is horizontally directly effective, so that the same duty also applies to private employers. $^{34}$

To the extent that an EU law right to work is legally enforceable as such, it might be possible to rely upon it against an employer who had either refused to recognize that right, or had refused to accept the evidence for it presented by the individual. Alternatively, it might be possible to claim that an employer had taken insufficient steps to confirm the right to work which the individual had claimed. In either case, the difficulty is to reconcile EU law rights to work with the requirements of the 2006 Act and its implementing legislation. If the civil penalty system, taken as a whole, provides sufficient possibility for persons who are entitled to work under EU law to

\footnotetext{
${ }^{33}$ Article 26 of the 2004 Qualification Directive (Council Directive 2004/83/EC, [2004] OJ L 304/12) confers an unrestricted right to work upon refugees. In the case of beneficiaries of subsidiary protection, it provides that member state's labour market situation 'may be taken into account ... for a limited period of time to be determined in accordance with national law', but the United Kingdom has not made use of this option. The option has been removed in most other Member States: see Article 26 of the recast Qualification Directive of 2011 (Directive 2011/95/EU of the European Parliament and of the Council of 13 December 2011 on standards for the qualification of third-country nationals or stateless persons as beneficiaries of international protection, for a uniform status for refugees or for persons eligible for subsidiary protection, and for the content of the protection granted (recast) [2011] OJ L 337/9).

${ }^{34}$ Case C-281/98 Angonese v Cassa di Risparmio di Bolzano [2000] ECR I-04139.
} 
prove their entitlement, it is arguable that an employer should not have to go further. That would mean a compromise position whereby EU law rights to work were enforceable within the terms of the 2007 Order, but not beyond it.

\section{Avoiding discrimination}

The limited possibility for legal rights to work to constrain individual employers means that the more important question in practice is whether employer attempts to comply with immigration law may fall foul of discrimination law. First, what if an employer differentiates in the nature of the checks imposed upon persons who are-or claim to be-in different categories? Secondly, what if an employer uses any information they obtain to favour some immigration statuses over others? In either case, the central question is whether employers discriminate on grounds of nationality. Under domestic law, that category of discrimination was previously prohibited for all employers by the Race Relations Act 1976, and is now contrary to the Equality Act 2010. In addition, nationality discrimination by employers is likely to be prohibited under EU law to the extent that the right to work in question is directly effective (discussed earlier), ie for all employers in the case of EU citizens, and for state employers alone in the case of other persons with an EU law right to work. $^{35}$

\footnotetext{
${ }^{35}$ In general, Article 18 TFEU prohibits discrimination on grounds of nationality 'within the scope of application of the Treaties'. Beyond that, Article 24 of the Citizens Directive provides for equal treatment with nationals of the Member State at issue 'within the scope of the Treaty', for EU citizens and their family members who are lawfully resident. The benefit of that rule extends to nationals of other EEA states by virtue of the Decision of the EEA Joint Committee 158/2007 amending Annex V (Free movement of workers) and
} 


\section{i. Differences in checks}

We saw in section II that British legislation does not set out a specific obligation upon employers to check any individual's permission to work. The absence of such an obligation has been offset by official statements, throughout the period since employer penalties were introduced, that ' $[t]$ he best way to ensure that you do not discriminate is to treat all applicants in the same way at each stage of the recruitment process. ${ }^{36}$ Since 1999 , that position has been supported by a statutory duty on the Home Secretary to publish a code of practice on compliance by employers with race discrimination law as they seek to meet their obligations under employer penalties legislation. ${ }^{37}$ While a breach of the Code by an employer does not lead to legal liability, it is stated in the legislation that such a breach 'may be taken into account by a court or tribunal'. The Code is therefore potentially relevant in proceedings concerning alleged discrimination.

Annex VIII (Right of establishment) to the EEA Agreement. Article 7(a) of the EU-Swiss Agreement on the Free Movement of Persons requires 'equal treatment with nationals in respect of access to, and the pursuit of, an economic activity', though without being clear whether it extends to their family members. There is no equivalent general statement in the legislation applicable to Turkish nationals and their family members, or that applicable to refugees and beneficiaries of subsidiary protection.

${ }^{36}$ See Home Office, Prevention of Illegal Working: Guidance for Employers (1996) 3; UKBA, Guidance for Employers on the Avoidance of Unlawful Discrimination in Employment Practice While Seeking to Prevent Illegal Working (February 2008) para 7.3.

${ }^{37}$ A code of practice was first required by the Asylum and Immigration Act 1996, s 8A, as a result of an amendment made by the Immigration and Asylum Act 1999. The current provision for the code is s 23 of the 2006 Act. 
In the conduct of employer checks, it appears self-evident that overt distinctions on the basis of nationality amount to direct discrimination. An example might be where an employer first asked each applicant their nationality, and then investigated the right to work only of those who did not claim British (or EEA) nationality. Alternatively, an employer might make assumptions about nationality from someone's appearance, accent, name, etc, and only ask for proof of the right to work from those assumed not to be British (or EEA) nationals.

Despite the apparently elementary nature of the conclusion that overt distinctions amount to direct discrimination, the Court of Appeal reached a different view in the pre-employer penalty case of Dhatt, decided in $1990 .^{38}$ That concerned an Indian national who had been refused employment, despite having indefinite leave and an unrestricted right to work, after an employer required proof of the right to work only of those who did not declare a (then) European Economic Community (EEC) nationality. The Court of Appeal held that the employer's policy did not breach the Race Relations Act 1976 as, through immigration legislation, Parliament had placed persons with an EEC nationality in a different position to others. Accordingly, in the language of the 1976 Act, the 'relevant circumstances' of the two groups were not the same. $^{39}$

The reasoning in Dhatt must be thought suspect even as the law stood at that time. In the absence of a statutory requirement upon employers to ensure that their

${ }^{38}$ Dhatt v McDonalds Hamburgers Ltd [1991] ICR 238. The case is treated here as concerned with recruitment, although the applicant was in fact suspended and dismissed soon after starting employment.

${ }^{39}$ See Race Relations Act 1976, s 5(4). For the corresponding language in the current legislation in the Equality Act 2010, see s 23(1). 
employees had permission to work, it was not clear why someone who claimed to be an EEC national was in a different position to a person who did not possess such a nationality. In Dhatt, the judges offered two different reasons - that an employer had a 'general responsibility' or 'public duty' to ensure compliance with the law by their employees, and that the employer risked criminal liability as an 'aider or abettor' of the employee's criminal offence if they did not do so. ${ }^{40}$ While each of those arguments explained why an employer might legitimately check job applicants' permission to work, neither appeared to justify differences of treatment on grounds of declared nationality within those checks. Once the employer had decided to check permission to work, the 'relevant circumstance' was that of being a job applicant, and there was no obvious rationale for exempting some applicants from the need to produce evidence, solely on the basis of the nationality they declared.

In any event, the subsequent introduction of employer penalties is a further reason to doubt the approach taken in Dhatt. Even though the legislation concerning employer penalties does not technically require checks, its effect is that employers should take responsibility for the permission to work of all employees. It is for that reason that provision is made within the secondary legislation for British and other EEA nationals to prove their nationality or right to work. Employer penalty legislation must be thought inconsistent with the notion that those who claim an EEA nationality are in a different position from those who do not, in relation to proof of entitlement to work.

\section{ii. Favouring certain immigration statuses}

\footnotetext{
${ }^{40}$ In Dhatt (n 38) Neill and Stocker LJJ advanced the former theory (247 and 249) while Staughton LJ favoured the latter (252).
} 
A further set of questions concern the outcome of employer checks within the recruitment process. If an employer were to differentiate on grounds of nationality as a result of the checks, then that would presumably amount to prohibited direct discrimination under the Equality Act 2010. What, though, if an employer favoured or disfavoured workers with certain immigration statuses, as evidenced by the immigration documents they produce $?^{41}$ In general, favouring those with secure immigration statuses would tend to favour British and other EEA nationals.

Conversely, favouring those with less secure immigration statuses would tend to favour other nationalities. Where an employer had a policy of doing either, there would be a risk of indirect discrimination, as the policy would involve the application of 'a provision, criterion or practice' which placed certain nationalities at a 'particular disadvantage', and the central question would be whether the policy was objectively justified. ${ }^{42}$

${ }^{41}$ For example, a study in 2008 found that some recognized refugees faced difficulty in proving a right to work to employers, apparently because they could not produce passports: Migrant Rights Network, Papers Please: The Impact of the Civil Penalty Regime on the Employment Rights of Migrants in the UK (2008) 14-15.

${ }^{42}$ Equality Act 2010, s 19. Note that, in the case of indirect nationality discrimination, the Race Relations Act 1976, s 1(1)(b) previously applied only to employer practices which amounted to a 'requirement or condition'. For a discussion of justification of indirect favouring of British or EEA nationalities by employers, see B Ryan, 'Transnationalism and Labour Law: The "British Jobs" Protests of 2009' in M Moreau (ed), Before and After the Economic Crisis: What Implications for the 'European Social Model'? (Edward Elgar 2011) 81-2. 
The UK Visas and Immigration guidance on discrimination and employer checks states only that employers should not favour applicants who produce List A documents over List B documents, as persons in the latter category might be able to extend their entitlement to work in Britain. ${ }^{43}$ The guidance does not, however, contain any general statement of principle that all statuses are to be treated as equally valid by employers. Neither does it explain why favouring some documents over others may breach discrimination law.

A general approach to the question of indirect nationality discrimination in the recruitment process may, however, be derived from the Employment Appeals Tribunal (EAT) decision in Obsorne Clarke Services v Purohit in $2009 .^{44}$ That concerned an Indian national whose application for a training contract had been rejected, because of the employer's policy of not considering applicants for whom a work permit would be required. The EAT firstly found that the policy put non-EEA nationals at a particular disadvantage. It went on to uphold the employment tribunal's finding that the policy lacked objective justification, as it was based on the 'conjecture' that a work permit would not be obtained, if applied for. In the EAT's words 'in the absence of any evidence as to dialogue with the [UK Border Agency (UKBA)] or any attempts to apply for a permit [the firm] did not begin to establish the level of evidence that is required to prove a justification on an objective basis. ${ }^{, 45}$

While Osborne was concerned with someone who did not have current permission to work in Britain, it is also relevant where an employer wishes to favour

\footnotetext{
${ }^{43}$ UKBA, Guidance for Employers on the Avoidance of Unlawful Discrimination in Employment Practice While Seeking to Prevent Illegal Working (February 2008) para 7.5.

${ }^{44}$ Osborne Clarke Services v Purohit [2009] UKEAT/0305/08/ZT.

${ }^{45}$ Osborne (n 44) [22].
} 
those with more secure immigration statuses over others. The implication of the ruling is that an employer cannot avoid a finding of indirect discrimination by relying upon generalizations as to the greater cost of employment of such a person with such a status. Instead, the employer would have to show a genuine need for someone with the requisite immigration status, and also why it could not be expected that a sufficient immigration status to meet that genuine need would be obtained. Conversely, favouring workers with less secure statuses is unlikely to be defensible in the same way. Even if an employer expected that workers with weaker statuses might require lower wages, or be more productive, it is hard to see that those considerations could provide an acceptable justification for the purposes of discrimination law.

\section{Checks During the Employment Relationship}

The next topic to be addressed is the legal position where an employer decides to investigate an individual's immigration status after the employment relationship has begun. Two issues are examined here: selection for employment checks during the employment relationship, and suspension pending the resolution of the individual's position, where they do not establish a current right to work to the employer's satisfaction.

\section{Selection for checks}

Employers who are familiar with immigration law must be thought likely to consider making employment checks during the employment relationship, at least in relation to workers who commenced employment on or after 29 February 2008, and who have previously presented List B documents. The employer may also contemplate checks 
on some or all of their other employees, in order to avoid differential treatment among them, or because of the organizational desirability of certainty about all employees' immigration status. The question to be addressed here is how an employer who is considering in-employment checks can avoid falling foul of the discrimination law principles examined in section III.

In order to comply with discrimination law, one option for the employer is to make checks on none of their employees after employment begins. That approach of course exposes the employer to liability where List B documents were initially presented by a post-29 February 2008 employee. It may be, however, that very few post-29 February 2008 employees present List B documents to begin with, or that very few employees who present List B documents remain for more than one year. From a legal perspective, one advantage for an employer of re-checking no one is that, without differentiation, no breach of discrimination law is possible.

For an employer who wishes to make checks after the employment relationship has begun, discrimination law presumably requires equivalent checks on all post-29 February 2008 employees who previously presented List B documents. Even if neutral criteria are used, selection within this group is likely to favour some nationalities over others, and therefore to risk indirect nationality discrimination, as there is no apparent objective justification for such differentiation. It also appears acceptable for an employer to check only those hired on or after 29 February 2008 who previously presented List B documents. While that approach would tend to favour EEA nationals over others, it would presumably be capable of justification with reference to the employer's purpose of avoiding liability under the civil penalty scheme. 
More difficult issues arise where an employer makes checks of immigration status during the employment relationship which include employees for whom this is not required under the civil penalty scheme. From the perspective of discrimination law, one option for an employer is presumably to make an equivalent check on the immigration status of all their employees. This could take the form, for example, of a check on all employees at a given point in time, or of a check at equivalent intervals within each employment relationship. While such a system of checks might seem excessive - and might have questionable motives - there cannot be a breach of discrimination law if there is no differential treatment.

By contrast, the employer might fall foul of discrimination law where they checked the status of only some of those for whom checks were not required under the civil penalty scheme. If such a selection were based on appearance, ethnicity, or nationality it would presumably amount to direct race discrimination. Alternatively, if the selection were based on an individual's previously demonstrated immigration status, it would risk indirect nationality discrimination, as it would tend to favour EEA nationals, without apparent justification. It is only where the selection criteria were unrelated to prohibited grounds or to immigration status that the employer might avoid liability under discrimination law. For example, an employer might operate post-employment checks of employees in some occupations, but not in others. Even then, if the effect were to favour some nationalities over others, an objective justification linked to employer need would have to be identified.

\section{Suspension}

If an employer has made an immigration check during the course of employment, what if they are not satisfied with the evidence of a current right to work provided by 
a given employee? As we saw in section II, once an employer 'knows' that a post-29 February 2008 employee lacks the right to work, they lose any protection from a civil penalty and commit a criminal offence. Against that background, an employer who is not satisfied may consider suspending or dismissing the employee. The legal position concerning suspension is examined here, while dismissal is addressed in section $\mathrm{V}$.

\section{$i$. The possibility to suspend}

Suspension after an unsatisfactory immigration check might serve a variety of purposes. An employer might have a genuine doubt as to whether the employee has a right to work or not, which they wish to investigate further. Alternatively, the employee might claim to be temporarily unable to provide any of the documents required under the civil penalty system, so that suspension provides an opportunity for those documents to be obtained. A third possibility is that suspension might allow an employee to improve their immigration status - perhaps with the assistance of the employer-for example, by leaving the UK and making an entry clearance application in an immigration category with a right to work. Finally, suspension creates an opportunity for consideration of the employer's final decision, if evidence of a current right to work cannot be provided, and there is no immediate prospect of providing it. ${ }^{46}$

\footnotetext{
${ }^{46}$ Suspension in an immigration context is analogous to what Freedland has termed 'precautionary suspension'. That involves 'the suspension of workers from work ... while allegations of evidence of misbehaviour are under investigation, or while the process of deciding whether they are to be disciplined or dismissed is taking place': M Freedland, The Personal Employment Contract (Oxford University Press 2003) 471.
} 
From a legal perspective, a key question is the status of the employment relationship during an immigration-related suspension. It is arguable that, during a suspension, the employment relationship is neither continuing nor terminated. ${ }^{47}$ In the immigration context, the particular advantage of suspension to the employer is to give them protection from the consequences of any 'knowledge' that they may acquire of an employee's lack of status. That in turn implies that any such knowledge need not necessarily lead to the termination of the employment relationship, but may instead permit other solutions to be found.

The employer's power to suspend the employment relationship for immigration status reasons is regulated by the contract of employment. Express contractual provision for such a suspension must be thought unlikely, so that any employer power will be based on an implied term of the contract. In employment law, the general test of implied terms is that they should reflect the nature of the employment relationship. ${ }^{48}$ Contemporary immigration law exposes both employers and employees to liability if an individual is employed without a right to work. ${ }^{49}$ It is also

\footnotetext{
${ }^{47}$ In Freedland's analysis (Freedland (n 46) 465) a period of 'contractual suspension' usually involves 'the transformation of the personal employment contract from the mode or state of contractual employment into the mode of being between periods of contractual employment, or sub-employment mode. Essential to this idea is the notion that the personal employment contract is transformed but not terminated when it moves into this subemployment mode.'

${ }^{48}$ See S Deakin and G Morris, Labour Law (6th edn, Hart Publishing 2012) 263-4.

${ }^{49}$ Employer civil and criminal liability was discussed in section 1 . An employee who works without permission is likely to commit an offence under the Immigration Act 1971, s 24, which prohibits illegal entry, overstaying, and breach of condition of immigration leave.
} 
significant that employees typically have more information about their immigration status, and more control over its proof, than do their employers. For both reasons, it might be thought to follow that employees are under an implied contractual duty to take reasonable steps to prove their continuing right of work, if required. By extension, employers must have the power to suspend where they have reasonable doubts concerning the individual's status.

\section{ii. Payment during suspension}

Payment during an immigration-related suspension raises further complex issues. On the one hand, employees with a right to work may legitimately object to being denied their wages. Their objection will be especially compelling where any difficulty with proof of a legal right to work is due to circumstances out of their control— such as the immigration authorities' delay in issuing the required document(s) —or is due to the employer's failure to accept the evidence of a right to work which has been presented. On the other hand, employers may consider it illogical to suspend an employee with pay when that person either does not have a right to work, or has failed to take reasonable steps to prove that they do so.

The legal position concerning payment during an immigration-related suspension has arisen in two cases before the EAT in recent years. The first was Kurumuth, in which the EAT delivered its full judgment in March $2011 .^{50}$ That concerned a Mauritian national employee who had been suspended without pay because of doubts about her immigration status. The employee actually had a legal right to work, because of an unresolved appeal against a refusal to extend her leave to remain, but

\footnotetext{
${ }^{50}$ Kurumuth v NHS Trust North Middlesex University Hospital [2011]
} 
was dismissed after a failure to provide evidence of that right to the employer. The employment tribunal rejected a claim under the contract for payment during the period of suspension. When an appeal against the tribunal decision was considered within the EAT's case management procedure, the judge (HHJ Peter Clark) concluded that the claim to payment during suspension had a 'reasonably arguable prospect of success', and the point was later conceded by the employer. ${ }^{51}$ The chair of the EAT which heard the appeal, HHJ McMullen, agreed that "while the Claimant was employed, she could not be suspended without pay ${ }^{52}$ (the unfair dismissal claim in the case is considered in section V).

The second case was the September 2011 decision in Okuoimose. ${ }^{53}$ That concerned a Nigerian national who was entitled to live and work in the UK as the spouse of an EEA national exercising free movement rights. When she commenced employment, her passport confirmed her right of residence as the family member of an EEA national, but later she failed to provide evidence of the extension of that right, and was suspended from employment. When UKBA then indicated to the employer that it could find no record of her having an ongoing application for a residence document, the employer dismissed her. In fact, the worker had by then applied for a residence card as the family member of an EEA national, and when UKBA issued her a 'certificate of application', the employer rescinded the dismissal. The claim in the case was for the wages that would have been paid during the period of suspension. In approaching that question, HHJ McMullen started from the proposition that the

\footnotetext{
${ }^{51}$ Kurumuth (n 50) [4].

${ }^{52}$ Kurumuth (n 50) [18].

${ }^{53}$ Okuoimose v City Facilities Management, [2011] UKEAT/0192/11/DA.
} 
applicant had at all times had a right to work in the UK, by virtue of EU law and implementing Regulations. It followed in his view that the contract of employment was not tainted by illegality, and that the wages she was denied through suspension were 'unlawfully deducted', and could be recovered. ${ }^{54}$

One question which may be asked of Okuoimose is which workers are covered by it. The EAT ruling is open to the narrow reading that it only concerns workers with a directly effective right to work under EU law (discussed earlier). It is at least arguable that these workers are in a special position, because their right to work is not conditional on the issuing of any document. Limiting the principle of payment during suspension in this way is, however, open to the objection that - as we saw in section I—no worker with a right to work is legally required to produce a document as evidence of that entitlement. The rationale in Okuoimose therefore appears applicable to all workers who are suspended for immigration reasons, but who actually have a right to work: ie all such workers should be able to claim payment for periods of suspension. That conclusion is moreover supported by the EAT's understanding of the matter in Kurumuth, which was not an EU law case.

Whichever view is taken of its scope, the ruling in Okuoimose is open to criticism for having focused on the employee's right to work, rather than on the implied terms of the contract of employment. One difficulty with that approach concerns those without a right to work, who would not then have a right to be paid during suspension. In most situations, an employer will, however, be unable to know in advance which category a given worker about whom there are doubts is in. A different solution potentially emerges if we ask which implied terms flow from the nature of contemporary employment relationships. Given the combination of employer's duties

\footnotetext{
${ }^{54}$ See Employment Rights Act 1996, s 13.
} 
under immigration law and employees' need for income security, it is arguable that all workers whose right to work is in doubt should be contractually entitled to payment during any immigration-related suspension. ${ }^{55}$

A second problem with reasoning from the right to work concerns the possibility that the suspension may have occurred because of - or may have been prolonged by - the employee's failure to take reasonable steps to prove their right to work to the employer. (The facts in each of Kurumuth and Okuoimose illustrate the general point.) Here, the problem with a focus on the right to work alone is that it may absolve the employee of any responsibility for proof. In contrast, within a contractual logic, it is arguable that an employee ought to take reasonable steps to prove their entitlement to work. Employers will, however, struggle to know which employees have not behaved unreasonably. Given the employee's need for income security, the conclusion under the contract is likely to be that all suspended employees should continue to be paid. An employer who considers that the employee has behaved unreasonably in relation to proof can instead have recourse only to dismissal.

\section{Dismissal}

Immigration checks after employment has commenced may eventually lead to dismissal. Two legal scenarios are examined here: dismissal after an error as to the

\footnotetext{
${ }^{55}$ It should be noted that the doctrine of illegality (discussed in section IV) precludes an employee without a right to work from bringing a legal claim based on the contract of employment. That doctrine goes to enforceability, however, rather than the initial question of entitlement under the contract.
} 
individual's right to work, and dismissal after a correct assessment that the individual lacks such a right.

\section{Right to work cases: dismissal in error}

The question of dismissal in error for immigration-related reasons was first addressed by the EAT in 1980, in Bouchaala ${ }^{56}$ That concerned a Tunisian national who had been dismissed after the Department of Employment had both refused an extension of his working visa and advised the employer that continued employment was illegal. After the dismissal, the Home Office wrote to the employer correcting its advice, as the applicant had previously been granted indefinite leave by an immigration officer. When the employee claimed unfair dismissal, the employer argued that the dismissal was justified by the need to avoid the contravention of a statutory duty. ${ }^{57}$ The EAT rejected that argument, reasoning that the 'statutory duty' justification was only available if continued employment would actually have been illegal. But it went on to conclude that the employer's genuine belief that there was 'an enactment prohibiting further lawful employment' fell within the concept of 'some other substantial reason', which was capable of justifying a dismissal. ${ }^{58}$ It therefore rejected the employee's

\footnotetext{
${ }^{56}$ Bouchaala v Trusthouse Forte Hotels [1980] ICR 721.

${ }^{57}$ Then Employment Protection (Consolidation) Act 1978, s 57(2)(d) and now Employment Rights Act 1996, s 98(2)(d). The 'statutory duty' justification covers legal obligations upon either the employer or the employee.

${ }^{58}$ See the then Employment Protection (Consolidation) Act 1978, s 57(1) and now the Employment Rights Act 1996, s 98(1).
} 
appeal against the decision of the industrial tribunal which had found the dismissal to be fair.

The reasoning in Bouchaala was followed by the Court of Appeal in November 2007 in Klusova, albeit with a different outcome. ${ }^{59}$ The applicant was a Russian national whose right to work was based upon an application for fresh leave. Before her immigration application was resolved, the employer dismissed her, after having been incorrectly advised by an office of the Immigration Service that the applicant no longer had a right to work. The employer sought to argue that the dismissal was justified under the 'statutory duty' heading, as continued employment would have been an offence under the 1996 Act. The first-level employment tribunal had, however, concluded that the worker had been entitled to work, and the Court of Appeal upheld the tribunal's finding. Having lost on that point, the employer was unable to succeed under the 'some other substantial reason' heading, as the employer had not followed the mandatory statutory procedure then in force. ${ }^{60}$

Essentially the same conclusion was reached by the EAT in Kelly $v$ University of Southampton in December $2007 .{ }^{61}$ That case concerned a US citizen for whom a work permit had been obtained for five years, but who had initially been granted leave to remain in the UK for only four years. Because she did not make an application for fresh leave until after her initial leave had expired, her initial leave was not extended automatically, and she was dismissed. On close examination of the statutory material, however, the continuing validity of the work permit meant that her employer was not

\footnotetext{
${ }^{59}$ Hounslow LBC v Klusova [2007] EWCA Civ 1127, [2008] ICR 396.

${ }^{60}$ Employment Rights Act 1996, s 98A, in force from 1 October 2004 to 5 April 2009.

${ }^{61}$ Kelly v University of Southampton [2007] UKEAT/0295/07/ZT, [2008] ICR 357.
} 
liable for the criminal offence set out in the 1996 Act. $^{62}$ Accordingly, the EAT found that the employer was unable to rely upon the 'statutory duty' justification for dismissal. Here, too, because the employer had not followed the statutory dismissal procedures, it could not rely upon the 'some other substantial reason' ground for dismissal.

A final case to consider under this heading is the EAT decision in Kurumuth, to which reference was made in section III. The employment tribunal there had concluded that the employer's decision to dismiss an employee who failed to give evidence of their right to work was substantively fair. The tribunal had also held that the dismissal was procedurally unfair, as the employer had dismissed the employee summarily once it concluded that there was no evidence of a right to work. Each of these findings was endorsed by the EAT. ${ }^{63}$ The outcome in Kurumuth concerning procedural unfairness is of particular significance, as the dismissal there came after the repeal of the statutory provision for automatic procedural unfairness which had been decisive in Klusova and Kelly.

The legal position is therefore again much as it was in Bouchaala-ie an employer's genuine mistake is not covered by the 'statutory duty' ground, but may be

\footnotetext{
${ }^{62}$ Section $8(1)$ of the 1996 Act permitted the strict rule requiring the employee to have permission under immigration law to be relaxed by statutory instrument. That had been done by Schedule 1, para 3 to the Immigration (Restrictions on Employment) Order 1996 and Article 3(3) of the Immigration (Restrictions on Employment) Order 2004, according to which the employer did not commit an offence if the employee was 'permitted to work under the Immigration Rules'. Note that there is no equivalent provision in the current legislation on civil penalties.

${ }^{63}$ Kurumuth (n 50) [12].
} 
classed as 'some other substantial reason'. If the employer wishes to rely upon that ground, the substantive fairness of the dismissal will be assessed by an examination of the reasonableness of that incorrect belief. In particular, the contribution of the immigration authorities, the employer, and the employee to that conclusion will be especially relevant. The employer will also have to show that the dismissal was procedurally fair, in the sense that the employee was given an opportunity to make representations after a decision to dismiss was taken. At the least, such a procedure ought to provide an opportunity (or a further one) for an employee to demonstrate that they are entitled to work.

\section{Dismissal where there is no right to work}

A different set of questions arises where an employer dismisses the employee after correctly concluding that they lack a current right to work. This subject was addressed in a coda to the judgment in Kelly. After having found that the applicant there could not have been dismissed for 'statutory duty' reasons, the EAT offered three reasons why a dismissal for that reason need not always be a fair one. The first was that the employee's lack of permission to work might have 'resulted from some past conduct or omission of the employer' ${ }^{64}$ Secondly, a dismissal might be unreasonable 'because something [could] readily be done in the future to remedy the position'. ${ }^{65}$ That was the position in Kelly itself, as, by the time of the dismissal, the employee had applied for indefinite leave with the employer's support. ${ }^{66}$ Thirdly, it might be appropriate to

\footnotetext{
${ }^{64}$ Kelly (n 61) [57].

${ }^{65}$ Kelly (n 61) [62].

${ }^{66}$ Kelly (n 61) [66].
} 
take certain procedural steps before a dismissal was finalized, particularly 'where the illegal state of affairs is disputed, or is technical, or arises from some kind of oversight which can be remedied by the time an [internal] appeal would have been heard. ${ }^{67}$ In the EAT's assessment, that case gave clear examples of procedural breaches, as the University had initially given the applicant a period of grace to resolve her immigration position, before then changing tack and dismissing without either a warning or a hearing. ${ }^{68}$

The doctrine of illegality is, however, a complicating factor in this context. The common law principle that an individual may not rely upon their own wrongdoing is taken to preclude claims under the contract of employment by workers who lack permission to work under immigration law. ${ }^{69}$ Accordingly, if a worker who lacks permission to work is dismissed, however arbitrarily, the current legal starting-point is that they cannot bring a claim of unfair dismissal. At the time of writing, the case of Allen v Hounga is before the Supreme Court, and may lead to a revision of the illegality rule in the employment context, in relation to both discrimination claims and (more optimistically) contractual ones. ${ }^{70}$ Even if the illegality rule continues to

\footnotetext{
${ }^{67}$ Kelly (n 61) [65].

${ }^{68}$ Kelly (n 61) [66].
}

${ }^{69}$ A recent example is Zarkasi $v$ Anindita and Tse Tan [2012] UKEAT/0400/11/JOJ. For a discussion of the doctrine of illegality in the employment context, see B Ryan, 'The Evolving Legal Regime on Unauthorized Work by Migrants in Britain' (2005) 27 Comparative Labor Law and Policy Journal 27, 43-8.

${ }^{70}$ This is the appeal from Allen v Hounga [2012] EWCA Civ 609. For a critique of the Court of Appeal judgment, see A Bogg and T Novitz, 'Race Discrimination and the Doctrine of Illegality’ (2013) 129 LQR 12. 
operate within employment law, it is conceivable that it might be relaxed in the kinds of circumstance discussed in Kelly — ie where the employer is at fault, or steps could readily be taken to remedy the situation, or the breach of the rules is technical in nature. For that reason, it is not irrelevant to speculate on the application of unfair dismissal law to a person without a current right to work.

\section{Conclusion}

On the evidence of this chapter, employer checks of immigration status have thrown up new and difficult questions within employment law. While plausible answers to many of these questions have been outlined by the courts, or may be deduced from general principles, room for uncertainty remains. At the recruitment stage, it is unclear how much weight is to be given to rights to work flowing from EU law, and also how far an employer may favour those with more secure immigration statuses. During the employment relationship, there are doubts as to the limits to employer selectivity in checks of current permission to work, and also in relation to the payment of employees who are suspended. In the event of dismissal, the more difficult issues concern those who lack a right to work: should they, too, have procedural or substantive protection in appropriate cases?

Legal questions arising out of employer penalties and checks are likely to continue to be a feature of employment law. At the policy level, there is no apparent pressure for a reversal of the civil penalties introduced in 2008, or for removal of the de facto obligation to re-check the status of many workers which they imply. At the same time, the share of foreign-born workers within the labour force has increased, from 7 per cent at the time employer penalties came into force in 1997, to 15 per cent 
by the end of $2013 .{ }^{71}$ If employer checks remain, and are applied to a highly diverse workforce, further clarification and adaptation of employment law principles by courts and tribunals seems unavoidable.

${ }^{71}$ The Labour Force Survey shows that 7.3 per cent of the employed population were foreignborn in the first quarter of 1997, as compared to 14.7 per cent in the fourth quarter of 2013. This figure covers men aged 16-64 and women aged 16-59, and includes both employees and self-employed. For a discussion of these trends, see C Rienzo, Migrants in the UK Labour Market: An Overview (Migration Observatory, August 2012). 


\begin{tabular}{|l|}
\hline \multicolumn{1}{|c|}{ Abstract } \\
This chapter argues that there are unresolved tensions between employers' duties \\
and current workers under immigration law. It examines the UK's comparatively late \\
introduction and development of employer checks on migration status. At the \\
recruitment stage, it highlights a lack of clarity regarding the need to respect a right to \\
work granted by EU law, and the freedom for an employer to prefer workers with a \\
particular migration status. During the employment relationship, the chapter identifies \\
legal uncertainties concerning employer selectivity in checks of current permission to \\
work, and in relation to the payment of employees who are suspended. Upon \\
dismissal, it shows that there are questions concerning the extent of the procedural \\
and substantive protection available to those lacking a right to work. \\
\hline Employer sanctions - UK immigration law - discrimination law - right to work - UK \\
\hline Keywords
\end{tabular}

